\title{
The Mystery of the Ascension and the Prayers at the Foot of the Altar
}

\section{Andrew Meszaros}

At the end of Mark's Gospel, we read: "So then the Lord Jesus, after he had spoken to them, was taken up into heaven, and sat down at the right hand of God" (Mk 16:19 RSV-2CE). ${ }^{1}$ The mystery of the Ascension, along with Christ's session (or sitting at God's right hand) has become theologically uninteresting, if not completely irrelevant, to many a practicing Christian.

"The doctrine of the ascension has become an enigma, if not an embarrassment," writes Douglas Farrow. "The corresponding liturgical feast, once one of the church's great feasts, is poorly celebrated. The Rogation Days that preceded it have disappeared and, whether marked on Thursday or on Sunday, Ascension pales beside Pentecost." ${ }^{2}$ In a different context, Robert P. Imbelli describes the feast of the Ascension as, by now, an "orphan feast," and laments how the Ascension is commonly thought of in terms of "absence"; the Ascension simply marks Christ's "sabbatical" until he "comes again."

The Paschal Mystery in common catechetical parlance typically denotes Christ's Passion, death, and Resurrection. For many, it is not at all obvious that the Ascension is missing from this series, which goes to show the contemporary neglect of this mystery. According to Sacrosanctum Concilium, the liturgy is meant to celebrate Christ's redeeming task that is accomplished by the Paschal Mystery, which includes "His blessed passion, resurrec-

\footnotetext{
1 Cf. Lk 24:51; Acts 1:9-1 1.

2 Douglas Farrow, Ascension Theology (London: Continuum, 2011) xi-xii.

3 Robert P. Imbelli, Rekindling the Christic Imagination: Theological Meditations for the New Evangelization (Collegeville, MN: Liturgical Press, 2014) 48-49.
} 
tion from the dead, and the glorious ascension." 4 The present article will uncover the extent to which the totality of the Paschal Mystery-which includes the Ascension-is mediated liturgically through the rite known as the Prayers at the Foot of the Altar, which can be found in the Roman Missal of 1962.

Perhaps one of the most controversial legacies of Pope Benedict XVI's pontificate was his Motu Proprio Summorum Pontificum ${ }^{5}$ which liberalized the use of the preconciliar liturgical books and established them as the Extraordinary Form of the Roman rite. Unfortunately, the document and its reception have done little to quell liturgical polemics and tensions. Indeed, such a situation is lamentable, especially if it inhibits a theological examination of parts of the Church's liturgical heritage.

Despite the post-conciliar removal of the rite of the Prayers at the Foot of the Altar from the Ordinary Form of the Mass, the rite has not ceased to retain a contemporary relevance, for believers and theologians alike. What is most significant to point out here is that, since Summorum Pontificum this particular rite has, de facto, received a more regular presence in the liturgical life of the Church. Moreover, the Church has also given additional space to the Prayers in contemporary liturgical rubrics, as it has done with the new liturgy for the Personal Ordinariates for former Anglicans. ${ }^{6}$

4 Second Vatican Council, Constitution on the Sacred Liturgy Sacrosanctum Concilium (4 December 1963) 5. Cf. Yves Congar, Jesus Christ (London: Geoffrey Chapman, 1966) 173: “...the Pasch, which embraces indissolubly the obedience of the cross, the resurrection, the ascension, and the sitting at the right hand of God."

5 Benedict XVI, Apostolic Letter Given Motu Proprio on the Use of the Roman Liturgy Prior to the Reform of 1970 Summorum Pontificum (7 July 2007).

6 In this sense, "Prayers at the Foot of the Altar," here, denotes any combination of appropriate preparatory prayers (e.g., the Aufer a nobis etc.) with the liturgical act of ascending to the altar, and is not necessarily limited to the rite as it is found in the 1962 Roman Missal. The Ordinariate Use officially includes a variation of the Prayers as an optional rite; see Divine Worship: The Missal (London: Catholic Truth Society, 2015). Another variation of the rite can be found, for example, in the post-conciliar 1965 missal, published as Ordo Missae: Ritus servandus in celebratione Missae et de defectibus in celebratione Missae occurrentibus (Vatican: Typis Polyglottis, 1965). This 1965 missal was implemented on the First Sunday of Lent, 1965. The option existed for the vernacular except 
The Prayers at the Foot of the Altar, therefore, are not a historical artifact. To the contrary, its current practice by Catholic ordained and faithful indicates, among other things, that its status as a locus theologicus cannot be completely ignored. Departing from the premise that the Prayers at the Foot of the Altar remain part of the liturgical heritage and practice of Christian worship, this article endeavors to explore the theological significance of this rite. The intention of the article is not to suggest ways by which the Prayers can be incorporated into the Ordinary Form. In this sense, the article is not programmatic. Nor is the article a technical study of the historical developments and mechanics of the rite. ${ }^{7}$ Rather, I will attempt to offer a theological reflection on the rite in itself, and argue that it is a privileged locus for mediating a mystery that remains relatively peripheral in the liturgical consciences of practicing Christians: namely the Ascension of our Lord.

I will proceed in three steps: first, by discussing the Ascension and its role in the economy of salvation and its theological significance for Christian life and worship; next, by addressing the way in which the Prayers at the Foot of the Altar, as a rite, liturgically mediate the mystery of the Ascension; and finally, by identifying some modest pastoral benefits that the rite can offer to the Catholic worshipper.

\section{The Ascension in the Economy of Salvation}

Examples of ascent (and descent) abound in the Bible. When the flood waters come, Noah's ark of salvation rises and is lifted up "high above the earth" (Gen 7:17), while it is the Lord who "sits enthroned over the flood" (Ps 29:10). To commune with God, Moses goes up the mountain where God dwells (Ex 24:18).

for the Eucharistic prayer (the Roman Canon), which was still to be said in Latin. It contained a simplified version of the Prayers at the Foot of the Altar, one which jettisoned Psalm 42, but retained the Introibo and the versicle dialogue, "P: Our help is in the name of the Lord. R: Who made heaven and earth. P: I confess.... The dialogue is between the priest and all the faithful."

7 It is for this reason that, for example, I do not refrain from using more popular texts to help shed light on what the Prayers at the Foot of the Altar meant for the individuals who celebrated them. 
In Old Testament Jewish worship, ascending stairs played a regular role. With the Temple itself built upon the elevated Mount, all those who entered the Temple, for example, had to climb the "Stairs of Ascent." Within the compound itself were a series of stairs that had to be climbed as one approached the Inner court and Sanctuary. On Yom Kippur, or the Jewish Day of Atonement, the high priest would ascend all of the stairs to the sanctuary, confess sins (his and all of Israel's), enter the Holy of Holies, sprinkle the sacrificed bull's blood (and then also the goat's) on the veil, and offer incense. The sprinkling of its blood on the veil of the Holy of Holies symbolized the meeting of heaven and earth and the accomplishment of right relations with God. ${ }^{9}$ Descending from the Holy of Holies, the high priest would perform benedictions before continuing the day's rituals. The liturgical ascent and descent of the High Priest during Yom Kippur symbolizes, in a sense, Moses' own ascent of, and descent from, Mount Sinai, a journey integral to establishing the Mosaic Covenant. The mountain is a divine meeting place, for which reason, the psalmist asks, "Who shall ascend the hill of the Lord? And who shall stand in his holy place?" The answer: "He who has clean hands and a pure heart" (Ps 24:3-4). ${ }^{10}$

For Christians, Jesus' coming is the fulfillment of the messianic expectation; he is the one who rules from "the holy mountain" (Ps 2:6; 3:4) and is to be worshipped on "his holy moun-

8 Pilgrims wanting to offer sacrifices in the temple would have had to climb these stairs to enter the Temple courtyard. These stairs, dating from the first century, were discovered by the Jewish archeologist, Benjamin Mazar (1906-1995).

9 For a concise and relevant discussion of the relationship between the Extraordinary Form (or more particularly, the Tridentine form of the Roman Rite) and its relationship to Jewish Temple worship, see Angela Costely, The Sacrifices of the Mass, Jewish Studies Master's Dissertation, University of Oxford, 2012. Costley essentially argues that the Tridentine form of the Mass is a Christianized Yom Kippur celebration.

10 Such references that express the relationship between God's presence, mountains (or heights) and the necessity of purity, can be replicated: "How awesome is this place! This is none other than the house of God, and this is the gate of heaven" (Gen 28:17) and "Do not come near; put off your shoes from your feet, for the place on which you are standing is holy ground" (Ex 3:5). "O Lord, who shall sojourn in thy tent? Who shall dwell on thy holy hill?" (Ps 15:1). 
tain" (Ps 48:1; 99:9). He is the Lord who sits at God's right hand (Ps 1 10:1,5). ${ }^{11}$ But Christ's ascent begins with a descent. The second person of the Trinity becomes incarnate, only to then be crucified. Douglas Farrow describes the story well:

He [Jesus] too ascends Zion triumphantly and is enthroned there. But his throne is a cross; his ascent is already a descent. That is the great twist in the plot, in the Christian telling of Israel's story, and it is immediately followed by another. Jesus rises from the dead on the third day....and ascends into heaven itself. ${ }^{12}$

Christ's Ascension is the fulfillment of his initial "descent," or Incarnation. The fall of Adam that constituted humanity's descent is reversed by the Logos' descent into human flesh, which is fulfilled in Christ's Ascension back into heaven. ${ }^{13}$ The Ascension is basically the symmetric counterpart to the Logos' descent, as Christ says in the Gospel of John, "No one has ascended into heaven but he who has descended from heaven, the Son of Man. And as Moses lifted up the serpent in the wilderness, so must the Son of man be lifted up, that whoever believes in him may have eternal life" (Jn 3:13). ${ }^{14}$

The significance of this passage from John's Gospel is twofold. First, the reference to Moses and the serpent indicates that the earliest Christians were conscious of the soteriological dimension of "elevation" or "ascent," rooted in the Old Testament. ${ }^{15}$ Second, St. Augustine comments that here, Christ's being "lifted up" refers not only to his elevation on the cross, but also his elevation into heaven. ${ }^{16}$ As Christ is the first fruits of Creation,

11 Cf. Rom 8:34; 1 Pt 3:22.

12 Farrow, Ascension Theology, 7.

13 Such a theological point is derived from a reflection on Christ as the "new Adam." See Rom 5:12-21; 1 Cor 15:45.

14 Cf. Jn 6:51-62; 8:28; 6:62; 16:28; Eph 4:8-10. See also the Catechism of the Catholic Church. With Modifications from the Editio Typica (New York: Doubleday, 1997) 659-667 (hereafter, CCC).

15 Subsequent Christian spirituality also takes up the theme of ascending in the spiritual life. Perhaps the most notable example here is The Ascent of Mount Carmel by St. John of the Cross in the sixteenth century.

16 See Dom P. Michel, "Le mystère de l'Ascension," in Les questions liturgiques et paroissiales 40 (1959) 105-126, at 114 . Cf. Augustine, Enarr. in Ps. 132 (PL 37:1735). 
this elevation also awaits his adopted sons and daughters. For it is God's children who will enjoy the rooms that Christ has prepared in his Father's house (Jn 14: 2-4). St. Paul writes in the letter to the Ephesians that by Christ's Resurrection, we have been raised up with him to "sit with him in the heavenly places" (Eph 2:5-6). St. Thomas Aquinas explains, "For since He is our Head the members must follow whither the Head has gone." 17

In this respect, the Ascension is both an act of grace and a saving act. ${ }^{18}$ It is an act of grace because with Christ's Ascension and heavenly session, humanity is brought to its truest and highest end: communion with God. ${ }^{19}$ It is a saving act because through it, Christ presents himself before the Father as a perfect offering and offerer, reconciling the world with God, achieving unsurpassable atonement, and hence, interceding for, and bringing salvation to, all. ${ }^{20}$

The Ascension, as the "spectacular prolongment of the Resurrection," 21 is the ultimate mystery of divine consolation: it encourages those who suffer and endure trials and burdens with the knowledge that glorification awaits them (cf. Lk 24: 26). And in our distress, it is the Lord in the heavens who intercedes for us now (cf. Rom 8:34; Heb 7:25), ${ }^{22}$ and it is he who represents us before God (Heb 9:24). It is for this reason that liturgical prayers are addressed "per Dominum nostrum Jesum Christum." 23

In God's Economy of Salvation, the Ascension plays a key role in the establishment of the New Covenant that Christ estab-

17 ST, III, q. 57, a.6, cor.: "Quia enim ipse est caput nostrum, oportet illuc sequi membra quo caput praecessit."

18 Farrow, Ascension Theology, 122.

19 Historically, it is by Christ's Ascension into heaven that Jesus' humanity definitively enters into heaven; our humanity's union with God is an object of theological hope. Cf. CCC, 665-666.

20 See Heb 9:14. Cf. ST, III, q. 57, a. 6, cor.

21 Michel, "Le mystère de l'Ascension," 108, 110. For reflections on the Ascension and the life of the Church as the ultimate confirmation of the Resurrection, see Tihamer Toth, La résurrection, l'ascension, la vierge Marie: Sermons prononcés dans l'église de l'Université de Budapest (Mulhouse: Éditions Salvator, 1936) 71-72.

22 CCC, 667: "Jesus Christ, having entered the sanctuary of heaven once and for all, intercedes constantly for us as the mediator who assures us of the permanent outpouring of the Holy Spirit."

23 Cf. Toth, La résurrection, $72-73$. 
lishes with the new People of God, the Church. ${ }^{24}$ The Ascension is not just Christ's departure from history, but is the condition for a new and more intimate presence of Christ: namely, Christ's presence in the Spirit. ${ }^{25}$ That Christ's Ascension (and "departure") is considered the precondition of a more intimate divine presence can be explained by the mystery's "economic" significance, or what it causes in our salvation.

According to Aquinas, the Ascension is the cause of an increase in all three theological virtues. ${ }^{26}$ It increases our faith because, if faith is the "conviction of things not seen" (Heb 1 1:1), then they who believe in him, but do not see him are truly blessed (cf. Jn 20:29). It increases our hope because our journey towards God progresses one step closer by virtue of our Head's entering into his Father's abode. And it increases our charity because it is precisely in Christ's going that the Spirit of love is "poured into our hearts" (Rom 5:5) and directs our wills towards "the things that are above" (Col 3:1).

Stemming from an increase in the theological virtues, Christ's disciples are able to adhere to him in an intimate, spiritual way. In the Economy, the Ascension sets off a causal chain that culminates in the liturgy: the Ascension begets Pentecost, the Church, and the Church's celebration of the Eucharist.

24 God's actions in his Economy are free; one act follows from another not out of necessity, but out of God's gracious providence, and so while we might give "fitting" reasons for why the Church proceeds from the Spirit which proceeded from Christ, one must do so in the spirit of obedience and awe. See, for example, John Henry Newman's sermon on Ascension Day, "Mysteries in Religion," in Parochial and Plain Sermons, Vol. 2 (London: Longmans, Green, and Co., 1908) 205-216, esp. 212-213.

25 Cf. John 16. The reflections here on the Ascension are heavily indebted to the article by Michel, "Le mystère de l'Ascension," 105-126. For the relationship between the Ascension and the Church with particular attention to John Henry Newman, see Donald Graham, From Eastertide to Ecclesia: John Henry Newman, the Holy Spirit, \& and the Church, Marquette Studies in Theology, 76 (Milwaukee, WI: Marquette University Press, 2011) 136-147. The Resurrection and Ascension are, respectively, the beginning and end of the "intermediate interval" that prepares the Church. See also Questions liturgiques: Studies in Liturgy 92 (2001), dedicated to the mystery of the Ascension.

26 What follows is a brief summary of ST, III, q. 57, a. 1, ad. 3. 
The cultic aspect of the Ascension is derived from Scripture, especially the Book of Hebrews and Revelation, according to which Christ is deemed the great and eternal High Priest, who, by the Ascension, enters the heavenly sanctuary, the Temple, which is not made of human hands (Heb 9:24; cf. Rev 21:22). ${ }^{27}$ Yves Congar, in his description of the divine origin of the Church, highlights the significance of heaven and Christ's presence there for us:

The design of grace does have a proper "place": heaven. Our Leader is there: Eph 1:20, 2:6; Col 3:1. From there He builds His body beginning with His Pasch-death-resurrection-being seated in the heavenly places-to which baptism unites us:... The ecclesial body of Christ is established on earth, by means of bodily mediation which put our bodies, that is, our whole persons, into contact with the paschal body of Jesus Christ, but it is built in heaven.... The body grows towards its heavenly Head... The Church is in the world...but what the Church does there is not of the world. It comes from on high and is leading on high. ${ }^{28}$

In sum, Christ's exercise of his High Priesthood in the Holy of Holies proceeds from his Ascension. There, both Priest and Victim, and having sent his Spirit to vivify the sacraments, Christ allows for worthy and perfect worship of the Father.

The Eucharist is not merely a memorial of the Cross and Passion. It is a sacred banquet that prolongs the vital communion offered by the resurrected Christ. The Ascension, then, as the continuation and culmination of the Resurrection, is what makes our Eucharist possible.

\section{The Ascension and the Prayers at the Foot of the Altar}

Both the Ordinary and Extraordinary Forms include references to the Ascension in the Creed and in their Eucharistic prayers. ${ }^{29}$ In addition to these two sparse verbal references, how-

27 For a concise reflection on Christ's priesthood, see Kenneth Baker, Fundamentals of Catholicism, 3 volumes (San Francisco: Ignatius Press, 1982-1983) II, 286-288. What is true of Christ's priesthood is true of his prophetic and kingly offices. Christ is King of Kings, Lord of Lords and the High Priest who rules and intercedes for us from on high.

28 Congar, Jesus Christ, 152.

29 Here we are concerned with Eucharistic liturgy, and not with other liturgical loci. There exists, for example, a significant variety of 
ever, the Extraordinary Form's offertory prayer, "Suscipe Sancta Trinitas," also mentions the Ascension; this prayer, like the Prayers at the Foot of the Altar, was removed from the Ordinary Form.

The Consilium charged with implementing the Liturgical Constitution eliminated the Prayers at the Foot of the Altar, presumably because such a removal was sanctioned by Sacrosanctum Concilium, $50 .{ }^{30}$ This article does not mean to revisit this decision. ${ }^{31}$

texts dedicated to the Ascension in the Liturgy of the Hours. The Ascension is also explicitly mentioned in Eucharistic prayers I, III, and IV. For the general liturgical presence of the Ascension, see Francis de Chaignon, Le mystère de l'ascension (Paris: Parole et silence, 2008) 7-40.

30 Annibale Bugnini, The Reform of the Liturgy. 1948-1975 (Collegeville, MN: Liturgical Press, 1990) 339. The relevant passage of Sacrosanctum Concilium, 50 states that, in order to manifest more clearly the "intrinsic nature and purpose of its [the Mass's] several parts...the rites are to be simplified, due care being taken to preserve their substance; elements which, with the passage of time, came to be duplicated, or were added with but little advantage, are now to be discarded."

There is something to be said for some liturgical dissonance caused by the rite in, for example, a Low Mass, which begins with the priest walking up to the altar with the vessels, descending the steps of the altar, only then to begin the Prayers at the Foot of the Altar. The upshot is that the priest announces that he is going "unto the altar of God" after he has already been there. Such historical anomalies, however, have been given a spiritual significance that cannot be simply dismissed. For example, one commentator from the seventeenth century interpreted the priest's initial ascent and then descent as the expulsion from Eden, only to then re-ascend in a prayerful and penitent manner (with the recitation of the penitential psalm etc.). See Thomas Gawen, A Brief Explanation of Several Mysteries of the Holy Mass and the Actions of the Priest Celebrating (London: Nath Thompson, 1686) 4-13. The author is "T.G.," most likely Thomas Gawen (1612-1683), fellow of New College, Oxford, convert to Catholicism. Ruth Jordan, "Gawen, Thomas (16121684)," Oxford Dictionary of National Biography, Oxford University Press, 2004 (http://www.oxforddnb.com/view/article/10470).

31 It can be noted now, in passing, that a liturgist as eminent and as seminal to the liturgical reforms that Vatican II envisioned as Joseph Jungmann S.J. felt that Psalm 42 in the Prayers was particularly apt for the celebration of the liturgy. See Joseph Jungmann, The Mass of the Roman Rite: Its Origins and Development (Missarum Sollemnia) (London: Burns \& Oates, 1961) 200-202. Describing the variations of the Prayers before Pius V, Jungmann states, not without potential relevance today, 
But before continuing, however, it might do well to justify why, after the suppression of this rite from the Ordinary Form, it is nevertheless worth examining its contemporary theological and pastoral significance.

First, the basic intention of the Prayers at the Foot of the Altar, as one concrete manifestation of the penitential rite, is still active in the Ordinary Form. That the Confiteor, for example, was maintained in the Ordinary Form goes to show that this penitential preparation for the Eucharistic act was never thought to be abrogated, but simply reformed, or simplified.

Second, the many constituent parts of the rite have significant historical precedent in the liturgical tradition of the West, despite the fact that liturgical scholars judge the rite as a wholeor as a "unit" - to have been incorporated into the Ordo Missae only rather "late" - that is, by Pius V in 1570.

The history of the Prayers at the Foot of the Altar is essentially a history of how all of its constitutive parts, originally the priest's private preparatory devotions, increasingly came to be bundled together and acquire a place within the liturgy itself. Indeed, Joseph Jungmann notes that the "the expression "prayers at the foot of the altar' is based on conditions which existed only after the year 1000 , because before the $11^{\text {th }}$ century there were, as a rule, no steps up to the altar," but only an elevated sanctuary. ${ }^{32}$ However, some form of preparation for the Eucharistic act in the form of a confession of sins, beseeching mercy, and a declaration of trust in God far predates the emergence of steps from which the rite derives its modern name. ${ }^{33}$ Jungmann observes, for example, that so-called apologiae, or self-accusatory locutions of unworthiness and guilt, are already present in the ancient Gallican liturgies; they enter into the Romano-Frankish liturgies in the ninth century, and experience a great proliferation by the eleventh century, especially at the begin-

that "This diversity of practice corresponded to the variety in spatial arrangements" (201). It seems not unreasonable to suggest that there might be other factors-pastoral as well as spatial — that would welcome at least the option of the Prayers today.

32 Jungmann, The Mass of the Roman Rite, 199.

33 For a brief survey of the rite, in addition to the work cited above by J. Jungmann, see Denis Crouan, The History and the Future of the Roman Liturgy (San Francisco: Ignatius Press, 2005) 58-62. For some of the variations of the practice, see Archdale A. King, Liturgy of the Roman Church (London: Longmans, Green and Co., 1957) 225-229. 
ning of the Mass. ${ }^{34}$ The Confiteor itself, a developed apologia, like the other prayers in the Prayers at the Foot of the Altar, began as a private preparatory devotion that was later incorporated into the liturgy. ${ }^{35}$ Private preparatory and vesting prayers in some places would be said in the sacristy, at others in the sanctuary, or in a side chapel. While Psalm 42's liturgical import for the newly baptized can be traced back to the fourth century, ${ }^{36}$ a tenth-century rubric for the recitation of Psalm 42 during the procession to the altar continued throughout the Middle Ages. A more solidified form of the Prayers is dated later from the eleventh and twelfth centuries, with their regimented order and location (i.e., before the altar) being regularized in the Roman Mass by the Missal of Pius V. ${ }^{37}$

That this particular ritual was introduced officially into the ordo late, was for many a Catholic thinker and pastor in the twen-

34 Jungmann, The Mass of the Roman Rite, 59-60. This is corroborated by Lerosey, who, for example, dates the elements of the Prayers at the Foot of the Altar as far back as the ninth century, citing the Pontificale de saint Prudence of 840 as containing them. See Auguste Lerosey, Abrégé du manuel liturgique à l'usage du séminaire de Saint-Sulpice (Paris: Berche et Tralin, 1893) 134. This book by Lerosey is an abridgement of the four-volume Manuel liturqique published in 1889.

35 Eugene Vandeur, The Holy Mass Popularly Explained (London: R. \& T. Washbourne, 1911) 36-37. Vandeur claims that this historical development explains why there are so many variations of the Confiteor. The devotional origin of the Confiteor is significant in that it highlights the fact that development in the liturgy in no way detracts from normativity. In other words, one cannot dismiss a liturgical practice simply on the grounds that it was an (late) accretion. This simply begs the question as to what is "late," and hence, demands further criteria to determine what is to be considered authentic and essential, on the one hand, and pastorally expedient, on the other.

36 Noële Maurice Denis-Boulet, "Analyse des Rites et des prières de la messe," in L'Église en prière. Introduction à la Liturgie, ed. Aimé-Georges Martimort (Paris: Desclée, 1965) 335-336. Cf. St. Ambrose of Milan, De Sacramentis, IV, 2, 7: St. Ambrose: Theological and Dogmatic Works, trans. Roy J. Deferrari, The Fathers of the Church, vol. 44 (Washington, DC: CUA Press, 1963) 229: "You came to the altar desiring to see the sacrament. Your soul says, And I will go in to the altar of God, to God who giveth joy to my youth'." See also Vandeur, The Holy Mass Popularly Explained, 33-36.

37 See Hans Bernhard Meyer, Eucharistie: Geschichte, Theologie, Pastoral (Regensburg: Verlag Friedrich Pustet, 1989) 217. 
tieth century no reason to belittle it. Ronald Knox, for example, writes colorfully about the fact that before the Tridentine reform, the Prayers may very well have been recited privately and inconspicuously by the priest:

If we were living in the time of King Henry VIII, I should be saying the psalm and the Confiteor while you were looking for your berets. But don't for that reason, think that this first part of the Mass doesn't matter...It's part of the Mass, now. And all the Mass belongs to you, and you to it... ${ }^{38}$

Indeed, that an element of the liturgy happens to be a later accretion is not in itself grounds for disregarding it. The rite of the Prayers at the Foot of the Altar remains, to this day, worthy of theological reflection, even if only a small minority of Catholics experiences it regularly.

The Prayers at the Foot of the Altar-according to the 1962 version of the Roman Missal-proceed thusly: the priest prays the Sign of the Cross and, beginning with the antiphon, Introibo ad altare Dei, recites Psalm 42, the lamenting and supplicatory Judica $m e .{ }^{39}$ (Here, $\mathrm{P}$ is for Priest, $\mathrm{S}$ is for Server):

P. Judge me, O God, and distinguish my cause from the nation that is not holy: deliver me from the unjust and deceitful man.

S. For Thou, O God, art my strength: why hast Thou cast me off? and why do I go sorrowful whilst the enemy afflicts me?

P. Send forth Thy light and Thy truth: they have led me and brought me unto Thy holy hill, and into Thy tabernacles.

S. And I will go in unto the Altar of God: unto God, Who gives joy to my youth.

P. I will praise Thee upon the harp, O God, my God: why art thou sad, O my soul? and why dost thou disquiet me?

38 Ronald Knox, The Mass in Slow Motion (New York: Sheed \& Ward, 1948) 4-5.

39 While the overall rite as a whole was maintained until the promulgation of the Novus Ordo, the recitation of Psalm 42 was made an optional element of the priest's individual preparation in 1964. See Denis-Boulet, "Analyse des Rites," 335-336. 
S. Hope thou in God, for I will yet praise Him: Who is the salvation of my countenance, and my God.

P. Glory be to the Father, and to the Son, and to the Holy Spirit.

$\mathrm{S}$. As it was in the beginning, is now, and ever shall be, world without end. Amen.

P. I will go in unto the Altar of God.

S. Unto God, Who gives joy to my youth.

P. Our help is in the Name of the Lord.

S. Who made heaven and earth. ${ }^{40}$

The priest and ministers then recite the Confiteor separately, followed by the four-versicle dialogue Deus tu conversus:

V. Thou wilt turn, O God, and bring us to life.

R. And Thy people shall rejoice in Thee.

V. Show us, O Lord, Thy mercy.

R. And grant us Thy salvation.

V. O Lord, hear my prayer.

R. And let my cry come unto Thee.

V. The Lord be with you.

R. And with thy spirit.

40 The English translation of the missal, slightly modified here, and in what follows in the rite, is taken from http://sanctamissa.org/en/ tutorial/ordo-missae-1.html. The original Latin can be found in Missale Romanum: Editio Typica 1962, Edizione anastatica e Introduzione a cura di Manlio Sodi e Alessandro Toniolo (Vatican City: Libreria Editrice Vaticana, 2007) 216-217. 
These prayers arouse compunction, humility, but also resignation, "confident appeal," ${ }^{41}$ and even joy in the one praying them. After the dialogue, the priest begins to ascend the altar, praying the Aufer a nobis:

Take away from us our iniquities, we entreat Thee, O Lord, that with pure minds we may worthily enter into the Holy of Holies. Through Christ our Lord. Amen.

Then he begins the Oramus te, saying, "We beseech Thee, O Lord, by the merits of Thy Saints," and kisses the altar, continuing, "whose relics are here, and of all the Saints, that Thou wilt deign to pardon me all my sins. Amen." The priest having ascended the altar, the Introit and Kyrie follow. ${ }^{42}$

The major link between the Prayers at the Foot of the Altar and the mystery of the Ascension is Christ's High Priesthood. ${ }^{43}$ Christ's Ascension into heaven is essentially his ascent into the Holy of Holies, into the bosom of the Trinity, into the presence of God. As such, the Ascension is essentially the mystery of Christ's High Priesthood. Now "as 'high priest of the good things to come'," Christ "is the center and the principal actor of the liturgy that honors the Father in heaven." 44 The Prayers, as a liturgical action, then, have the ascended Christ as its principal agent.

41 Knox, The Mass in Slow Motion, 8.

42 In the event of a Sung Mass, the Introit is sung while the priest and ministers recite quietly the prayers.

43 Here one might situate this link within the broader "exchange" between Christ's presence in the flesh and Christ's presence in the Spirit. Christ's priesthood is exercised by the Spirit because he has ascended. This is in accord with the Johannine texts such as 20:17: "Touch me not, for I have not yet ascended to My Father." Christ's disappearance is the cause of his sacramental presence inaugurated by Pentecost. This is most evident in the relationship between Christ's glorified body that is in heaven and his Eucharistic body participated in by the Church. See Graham, From Eastertide to Ecclesia, 143-144. In addition to the High Priesthood, another connection between the Prayers at the Foot of the Altar and the Ascension is Moses entering into the cloud. See Vandeur, The Holy Mass Popularly Explained, 40; Nicholas Gihr, The Holy Sacrifice of the Mass: Dogmatically, Liturgically and Ascetically Explained (St. Louis, MO: Herder, 1902) 347.

$44 C C C, 662$, with reference to Heb 9:11. 
The Prayers at the Foot of the Altar are that rite by which the faithful participate in Christ's ascent into the Holy of Holies. Liturgically speaking, we are "caught up" into this upward dynamic, carried to the Holy of Holies that Christ has opened up for us by his Ascension. We can ascend and go to the altar of God because Christ has ascended into heaven. Christ the Head is in heaven, and He is leading his Body, which is still on earth, towards its celestial destiny.

Such an understanding of the Prayers at the Foot of the Altar, and the Mass generally, stands or falls with the Catholic interpretation of Hebrews 9 and whether the Mass is indeed the fulfillment, on this side of heaven, of Jewish Temple worship. ${ }^{45}$ Whether Christian worship as such abolishes Jewish Temple worship or fulfills it is a theological debate that came to a head during the Reformation when the sacrificial nature of the Mass was disputed. ${ }^{46}$ The Catholic position, which holds essentially that

45 For a systematic theological reflection on the relationship between the Eucharist and Jewish worship, see Mathew Levering, Sacrifice and Community: Jewish Offering and Christian Eucharist (Malden, MA: Blackwell, 2005). That Christian worship is the fulfillment of Jewish sacrifice is lent further credence by the inclusion of similar rites and prayers in other rites more ancient than the Tridentine and other than the Roman. For example, the Mozarabic rite contains both the Judica me and the antiphon; the Milanese rite has merely the antiphon but not the Judica me. Both eastern and western liturgies used to have a Davidic psalm that expressed the desire to offer worthy sacrifice in the temple. (For these examples, see Gihr, The Holy Sacrifice of the Mass, 353, n. 1). In the Byzantine rite, this is the penitential psalm 50 (51), which is recited till verse 17. In the Roman, it is Psalm 42. It can also be noted that the Byzantine rite further appeals to Yom Kippur in that it combines the vesting and lavabo rites, just as the High Priest bathed before entering the Holy of Holies (See Costley, The Sacrifices of the Mass, 21). Also relevant here is the western rood screen or altar rail and the eastern iconostasis, both versions of the veil- 'type' of the Old Testament.

46 See, for example, Reinold Theisen, O.S.B, Mass Liturgy and the Council of Trent (Collegeville, MN: St. John's University Press, 1965), esp. 20. For a stimulating discussion on the relationship between early Christians, on the one hand, and "Temple" (or, alternatively, "Synagogue") theology, on the other, see Margaret Barker, Temple Themes in Christian Worship (London: T\&T Clark, 2007). My position assumes what Barker seeks to establish: namely, that Yom Kippur, or the Day of Atonement, 
Christian worship fulfills Temple worship through Christ, the High Priest, becomes evident when one reflects on the Prayer at the Foot of the Altar.

The priest is leading the faithful to the altar of God who gives joy to their youth-or nourishment for their rebirth in Christ and the Spirit. ${ }^{47}$ The priest prays that he may worthily enter the Holy of Holies, ${ }^{48}$ which was traditionally entered only once every year at Yom Kippur in order to offer sacrifice for the sins of the Jewish people. This has been understood to be a "type" of the new Holy of Holies in the New Covenant, ${ }^{49}$ and the liturgical altar today is a "type" or "figure" of the celestial Holy of Holies. ${ }^{50}$ Like the complex series of purificatory washings that the high priest would undergo before he entered the Holy of Holies, so too the Christian priest, by all the penitential prayers, but especially in the Aufer a nobis, asks that his soul be spotless, for only "he who has clean hands and a pure heart" can go up to the mountain of the Lord (Ps 24). Just as blood was sprinkled therein on the veil, so too the Christian priest enters the sanctuary, where he will make present the sacrifice of Christ that was offered once and for all (Heb 10:10).

Christ, by his Ascension into the heavenly sanctuary, initiates for us the celestial liturgy of his own sacrifice, as both priest and victim. Christ's Ascension is the heavenly Introit of this

played a central role in early Christian theological and liturgical development. Barker goes further to argue that the "Synagogue" tradition and Passover themes hold a second place to the Temple tradition as being that which is believed by early Christians to have been fulfilled by Christ.

47 Gihr, The Holy Sacrifice of the Mass, 352.

48 See the Aufer a nobis prayer above.

49 For an in-depth study on the relationship between Yom Kippur and Christianity, see Daniel Stökl Ben Ezra, The Impact of Yom Kippur on Early Christianity, Wissenschaftliche Untersuchungen zum Neuen Testament, 163 (Tübingen: Mohr Siebeck, 2003). Stökl Ben Ezra notes that the question he investigates is not whether Temple typology was used by Christians (it was and this is overwhelmingly substantiated), but rather what conclusions can be drawn from this appeal. For example, does an early Christian author's use of Temple-typology necessarily mark his rejection of Temple worship? (p. 330).

50 Lerosey, Abrégé du manuel liturgique, 136. 
liturgy. Dom Michel goes so far as to say, "One can place on his [Christ's] lips these words which begin the Mass: Introibo ad altare Dei." 51

That a re-presentation of the Ascension is one of the spiritual imports of the Prayers at the Foot of the Altar is further substantiated when we consider the symbolic meaning attached to the various liturgical actions within the rite. For example, one commentator, writing in the nineteenth century, observes that the priest begins the prayers-that is, before he begins his ascent to the altar-with a genuflection or bow. This common liturgical action, according to this commentator, is meant to recall the humble descent of the Logos to earth; ${ }^{52}$ only after the descent does the priest proceed to ascend..$^{53}$

In addition to the ascent into the Holy of Holies, the liturgical mediation of the Ascension also takes place through the benediction and dismissal. In Luke's Gospel, for example, Christ blesses the apostles as he is being taken up ( $\operatorname{Lk} 24: 51)$, and in Mark, he ascends after he has told them to "Go into all the world..." (Mk 16:15). In both Ordinary and Extraordinary Forms, the priest blesses and (the deacon) sends. But without a more explicit rite of ascent (such as the Prayers at the Foot of the Altar), the Biblical ascension-context of this benediction and mission is lost. ${ }^{54}$ Associated with this ascension-context is, for example, the irrevocable promise of divine presence in the Church. Moreover, the ascension-context of the liturgical blessing and sending helps communicate-however implicitly-that this mission and blessing from the glorified and risen Christ are a means to the ultimate ascent of the entire world to heaven. Christ's Ascension is the

51 Michel, "Le mystère de l'Ascension," 117.

52 Lerosey, Abrégé du manuel liturgique, 134.

53 This "kenotic" interpretation of the Prayers at the Foot of the Altar coheres with the symbolism of the celebrating priest representing Christ in the garden before his Passion. See Raphael Clynes, O.F.M., Liturgy and Christian Life (Paterson, NJ: St. Anthony Guild Press, 1960) 58.

54 The same necessity of liturgical ascent is important for the proclamation of Christ's second coming in the Mysterium fidei after the Eucharist is confected. Christ's Ascension is given to us as a key to opening up our imaginations to his final return: "This Jesus...will come in the same way as you saw him go into heaven" (Acts 1:10). 
ultimate reminder that the Church is called to continue the work of Christ on earth, and that she is utterly dependent on her Lord to do so. ${ }^{55}$

The principle distinction between Christ's Ascension and the cultic ascent to the altar is the eschatological and liturgicalsacramental character of the priest's ascent. The priest's ascent is eschatological in that the terminus of the ascent is not, strictly speaking, the "heavenly places" that are prepared for the saints, but the sanctuary in which heaven and earth meet. One aspect of this eschatological dimension is that the priest's ascent, unlike Christ's, is a penitential ascent-one that is conscious of sin and, therefore, of the necessity of grace bestowed through the liturgy in order to, ultimately, follow Christ to the "heavenly places." 56 The eschatological tension between the pilgrim Church worshipping here and now, and the celestial Church (triumphant) who are spiritually present at the liturgy is visibly manifested in, for example, the altar that is venerated by the ascended priest. To this altar, the site of Christ's redemptive death, are, traditionally, joined relics of those men and women who are united to him. The sanctuary, in a sense, is where Christ's body in its pilgrim state encounters itself in its eschatological fulfillment. The priest's ascent, then, not only represents Christ's historical ascent, but is a liturgical and eschatological ascent of the entire community to its final end.

In other words, the priest's ascent is liturgical-sacramental in that he is playing a mediatory role between God and His people. He not only acts in Christ's person, but also on behalf of the faithful, confessing sins, and beseeching to worship worthily. Christ's Ascension, from the worshippers' liturgical standpoint, is clearly a pledge, the first fruit of what is to come, and the cause of what we accomplish sacramentally.

\section{Conclusion: The Pastoral Significance of the Prayers at the Foot of the Altar}

The final section of this article comes after having sought to uncover the relationship between a liturgical ritual, on the one

55 Toth, La résurrection, 67-70.

56 The penitential dimension of the ritual, expressed most strikingly by the extended bow during the Confiteor, calls to mind Sir 35:21, "The prayer of the humble pierces the clouds..." See Vandeur, The Holy Mass Popularly Explained, 39. 
hand, and a mystery of the faith, on the other. In what follows, I will first summarize the relationship between this rite and the Ascension. Then I will suggest some additional pastoral benefits that might be available to those who participate in the rite.

The connection between the Prayers at the Foot of the Altar and the Ascension of Christ is a profound one. According to the liturgical theologian David Fagerberg, the liturgy is essentially "faith in motion." ${ }^{7} 7$ Here, one might venture to say that the Prayers is the mystery of the Ascension in motion. ${ }^{58}$ One could even say that that the lex orandi of the Prayers illuminates the lex credendi of what is professed each Sunday: "and he ascended into heaven, and is seated at the right hand of the Father." In addition to the Ascension being the crowning moment of Christ's glorification, it is also the source of Christ's intercession in the economy of salvation. The Prayers makes more sacramentally explicit the fact that the faithful are being led by their high priest into the holy of holies that Christ has opened for them. Through its allusions to Jewish Temple worship, the Prayers reveal concretely the intercessory and sacrificial dimensions of the Ascension. Conversely, the mystery of the Ascension, as it is articulated in the doctrinal tradition of the Church, and especially as it is elaborated upon in the Scriptures (particularly in the book of Hebrews), helps clarify the liturgical significance of this rite that had an official place in the Mass for centuries.

Without arguing for the implementation of the Prayers into the Ordinary Form, much less offering a program for such an implementation, I simply want to suggest some of the pastoral benefits that the Prayers at the Foot of the Altar offer those who participate in the rite today, whether in the Extraordinary Form, or in certain Ordinariate liturgies. ${ }^{59}$

57 David Fagerberg, What is Liturgical Theology? A Study in Methodology (Collegeville, MN: Liturgical Press, 1992) 75.

58 One of course, should qualify this. The mystery of the Ascension cannot be "captured" in one liturgical act, nor is the liturgical import of the Prayers at the Foot of the Altar limited to mediating the mystery of the Ascension.

59 Such a discussion need not preclude, for example, the future possibility of incorporating the Prayers at the Foot of the Altar into the Ordinary Form, especially were it to be audible with communal responses as it was immediately after the Second Vatican Council according to the Missal of 1965.This proposal is made here in passing in answer to 
The first thing that the Prayers offer those who participate in them is a sense of liturgical dynamism. By "sense of liturgical dynamism" I mean both the knowledge and the experience that the faithful have of the liturgy being a process that leads its participants deeper into the bosom of the Trinity. In an ideal liturgy, the faithful's experience-that is, their taste, sight, and smell etc. - of the sacraments would be in some way proportional to, or better, revelatory of, the mysteries which they know, in fact, to be participating in. If the Ascension gives the Church a sense of direction, so too should the liturgy. ${ }^{60}$ In this case, the transition from a liturgical posture of kneeling to standing reflects the upward motion of the Ascension, as do the prayers that the priest says, along with his upward ascent to the altar. Since the Ascension is an essential component of the Paschal Mystery which the liturgy celebrates, and since the Ascension is a mystery that involves Christ's ascent to the Father, the celebration of the Prayers at the Foot of the Altar is a privileged rite that communicates this upward dynamic, and confirms on an experiential level what the faithful believe: namely, that the Mass is one great lifting of the heart to God in prayer. The Prayers are that visible rite that gives the faithful the opportunity to profess their discipleship, and thereby to confirm Christ's words: "My sheep hear my voice... and they follow me" (Jn 10:27). It also offers a visible reminder of how the Mass in which they are currently participating is in fact made possible by Christ's historic session and intercession in heaven.

In addition to a sense of liturgical dynamism, the Prayers at the Foot of the Altar offer the faithful a more extensive opportunity to acquire the penitential disposition necessary for Mass. As the Ordinary Form exhorts, we call to mind our sins in order

Pope Paul VI's exhortation (summarized by Bugnini) that the penitential formula be one in which "the congregation can participate (unlike the present prayers at the foot of the altar, in which only the celebrant and servers have a part)." See Bugnini, The Reform of the Liturgy, 346.

60 For commentary on the Ascension as that which offers the Church a "sense of direction" and a "dynamic force," see W. H. Marrevee, The Ascension of Christ in the Works of St. Augustine (Ottawa: University of Ottawa Press, 1967) 147-148. See also Anthony Dupont, "Augustine's Sermones ad populum on the Feast of the Ascension," in Questions Liturgiques: Studies in Liturgy 92 (2011) 340-360, esp. 340, n. 9, where he quotes Marrevee. 
to help prepare ourselves to celebrate the sacred mysteries. What has become not uncommon in many Sunday liturgies, however, is a penitential rite that omits the Confiteor and simply gives the faithful a few seconds to "call to mind" their sins before beginning the Kyrie. The Prayers, on the other hand, not only extend the penitential rite by always including the Confiteor, but also include the penitential posture of kneeling, and the recitation of the encouraging Psalm 42. More time and prayer, therefore, is offered in order to develop a penitential attitude, which not only prepares the liturgical participants, but also impels them towards what is to come. ${ }^{61}$

This penitential disposition is important, not least, because it highlights the gravity and gratuity of the liturgical action. Commenting on how the Prayers at the Foot of the Altar are intended to evoke a certain "shyness" in our liturgical disposition, Knox, already before the Council, speaks to us today: "We're terribly in danger all the time of taking God's goodness too much for granted; of bouncing up to Communion as if it were the most natural thing in the world, instead of being a supernatural thing belonging to another world. So first we must be shy about it."62 This "shyness" of which Knox speaks is but one mild way of expressing a certain fear, trembling, and humility that he would exhort participants of the liturgy to cultivate.

Moreover, I would suggest that the sense of liturgical direction and penitence which the Prayers at the Foot of the Altar

61 A penitential disposition is also, to my mind, key to the New Evangelization, for such a sense of sin is essential to recognizing the necessity of faith. The Christian faith, along with its liturgy, has little if any raison d'être if there is no personal sin. And at a time when the Church is under heavy scrutiny for moral failure, it is all the more necessary to cultivate a penitential attitude among Christians (and to let this be what the world sees when it looks into the liturgy). The rite is particularly striking when the faithful (or the ministers) beseech God to forgive the priest's sins after the priest's recitation of the Confiteor. It is not a little ironic that in a post-conciliar age in which it is fashionable to emphasize the priesthood of the all the baptized, one of the key moments when this priesthood is explicitly exercised in relation to the ministerial priesthood is abandoned: namely that moment in which the altar servers or ministers (on behalf of the faithful, or in 1965, with the faithful), intercede for the ministerial priest (i.e., the main celebrant).

62 Knox, The Mass in Slow Motion, 8. 
foster in fact draws more attention to the Eucharistic pinnacle of the liturgy. From the start, the Prayers articulate the faithful's destination: namely, the altar of the Lord. And the sense of sin that the Prayers elicit in us can only increase our desire to partake in the Body and Blood that is shed for the forgiveness of sins. The Eucharist itself, cibus viatorum, is food for the journey to that heavenly banquet where Christ has ascended.

Andrew Meszaros, Ph.D. is a postdoctoral researcher of the Flemish Research Council (F.W.O.) at the Catholic University of Louvain (KU Leuven), Belgium. 